\title{
SITONA LEPIDUS GYLLENHAL NEWLY ESTABLISHED IN NEW ZEALAND: ASSESSMENT OF DISTRIBUTION IN THE NORTH ISLAND
}

\author{
GARY M. BARKER ${ }^{1 *}$, PAUL J. ADDISON ${ }^{1}$, ALAN C. FIRTH ${ }^{1}$ \\ and BARBARA I.P. BARRATT ${ }^{2}$ \\ ${ }^{I}$ AgResearch, Ruakura Agricultural Research Centre, Private Bag 3123, Hamilton \\ ${ }^{2}$ AgResearch, Invermay Agricultural Centre, Private Bag 53002, Mosgiel \\ *Currently Landcare Research, Private Bag 3127, Hamilton
}

\begin{abstract}
Sitona lepidus has recently established in New Zealand, being first recognised in pastures in the vicinity of Hamilton (Waikato) in March 1996. The distribution of this species in the North Island was ascertained from retrospective examination of curculionid samples collected from pastures during the period February 1995 to March 1996, and from a contemporary field survey of curculionids from pastures during MarchApril 1996. Collectively, these surveys provided coverage of the North Island from Te Hana, Northland to Masterton, Wairarapa. S. lepidus was confirmed as being widespread in the Auckland, north Waikato and coastal Bay of Plenty regions, but was not found south of these regions.

Keywords: Sitona lepidus, pasture, distribution
\end{abstract}

\section{INTRODUCTION}

The genus Sitona Germar (Coleoptera: Curculionidae, Brachycerinae) has a natural Holarctic distribution and comprises a large number of species. Some are pests of forage and grain legumes, with several species being widely distributed and naturalised beyond their natural range. Sitona discoideus Gyllenhal has become widely distributed in New Zealand since first being reported in Napier in 1974 (Esson 1975). It rapidly became established in lucerne (Medicago sativa L.) crops throughout New Zealand, causing considerable crop losses (Kain and Trought 1982; Goldson and French 1983). This species also occurs widely in New Zealand in non-agricultural habitats, where other Medicago species are the primary host plants (Barker and Addison unpublished). In 1982, a parasitoid Microctonus aethiopoides Loan (Hymenoptera: Braconidae, Euphorinae) was introduced as a biological control agent for $S$. discoideus at several South Island sites (Stufkens et al. 1987). The parasitoid has become widely distributed throughout New Zealand (Stufkens et al. 1987; Ferguson et al. 1994; Barker and Addison unpublished) and provides good control of S. discoideus in South Island lucerne crops (Goldson and Proffitt 1986; Goldson et al. 1994).

In March 1996, it was confirmed that a second Sitona species, S. lepidus Gyllenhal, was present in New Zealand (Barratt et al. 1996). Its presence was first recognised in March 1996, when weevils of reproductive phenology inconsistent with that of S. discoideus were collected from pastures at the Ruakura Agricultural Research Centre dairy farm near Hamilton. Closer examination of specimens, including comparison of genitalia preparations, confirmed that the Waikato infestations were indeed not that of S. discoideus but that of another Sitona species. Dr G. Kuschel (Auckland, formerly Landcare) subsequently examined this material and confirmed it as $S$. lepidus.

S. lepidus is a Palaearctic species (Dieckmann 1987), that has become widely distributed in North America since establishment there in the 1870s (Bright 1994). It feeds on a range of legume species, particularly red (Trifolium pratense L.) and white (T. repens L.) clovers. Currently, it is not possible to predict the potential pest status of this species in New Zealand. 
This paper documents the results of a survey undertaken to ascertain the distribution of S. lepidus. The primary objective was to determine whetherS. lepidus was restricted to the site where it had initially been found, or whether it had established more widely in the North Island.

\section{METHODS}

Retrospective examination of Waikato and north North Island specimen material

Curculionid material was available from several surveys, allowing retrospective assessment of the distribution of S. lepidus at sites in the vicinity of Hamilton, prior to the recognition of this species at the Ruakura Agricultural Research Centre. The samples had been collected from pastures as part of a programme investigating the dispersal rate of the Argentine stem weevil (Listronotus bonariensis (Kuschel)) parasitoid $M$. hyperodae Loan. Pastures from up to a $25 \mathrm{~km}$ radius of Hamilton had been sampled using a suction apparatus at several dates during the period February 1995 to March 1996 and all Curculionidae from those samples were held at $-20^{\circ} \mathrm{C}$ at Ruakura Agricultural Research Centre pending identification and dissection.

Following confirmation of $S$. lepidus at sites beyond the initial site of discovery, curculionid material that had been collected more widely in the northern North Island was also inspected. This material had been collected from pastures in the ReporoaBroadlands (Bay of Plenty) and Te Hana-Wellsford (Northland) districts, again to document $M$. hyperodae dispersal, at various dates from February 1995. In addition, a large number of pasture sites had been sampled in January-February 1996 to provide curculionid faunal assemblage data and to document habitat overlap between indigenous and naturalised species. This material had been collected by pitfall trapping and suction sampling and was held in $70 \%$ alcohol. Additionally, as part of extension activities, curculionid material had been collected opportunistically from various pasture sites by suction sampling and sweep net sampling since 1991 . This material was held at $-20^{\circ} \mathrm{C}$. Field survey

A survey was undertaken in Northland, Auckland, Waikato, Bay of Plenty, King Country, Taranaki, Manawatu, Wairarapa, Hawkes Bay, and Poverty Bay to provide for a more definitive assessment of the current distributional limits of S. lepidus. Pastures were sampled during the period 22 March to 1 May 1996 by suction apparatus, with a $100 \mathrm{~m}$ transect taken across the paddock. The presence of S. lepidus was recorded and all curculionids obtained were stored at $-20^{\circ} \mathrm{C}$.

In each phase $S$. lepidus was distinguished from its congeneric $S$. discoideus using the diagnostic key developed by Barratt et al. (1996), with vestiture of the elytra, structure of the frons between the eyes, and the relative size and position of the eyes as the principal diagnostic external characters.

\section{RESULTS}

The retrospective samples from the Waikato indicated that S. lepidus was distributed beyond the site at which it had been first recognised in March 1996. The stored samples showed that the species had been present in pastures in an arc of about $25 \mathrm{~km}$ radius, centred on Hamilton, from Ngaruawahia to Kaipaki during the period February to September 1995 . Several sites within the $25 \mathrm{~km}$ radius to the west and south-west of Hamilton did not yieldS. lepidus(Fig. 1). Pasture in the Waikato beyond the $25 \mathrm{~km}$ radius from Hamilton had not been sampled.

The retrospective samples from Te Hana-Wellsford (Northland) and ReporoaBroadlands (Volcanic Plateau, Bay of Plenty) districts, Otamarakau (coastal Bay of Plenty), and Tolaga Bay, Waiohika and Patutahi (coastal Poverty Bay), taken in 1995, did not yield S. lepidus (Fig. 1).

The contemporary sampling, March-April 1996 (Fig. 1), showed S. lepidus to be widely distributed in the Waikato Basin, north of about latitude $38^{\circ} \mathrm{S}$, and extending into the coastal Bay of Plenty. The species was recorded in dairy pastures adjacent to Auckland International Airport and extending north to Warkworth. Sampling at five sites in South Auckland failed to yield S. lepidus, indicating a zone of absence between the Auckland and Waikato centres of distribution. 


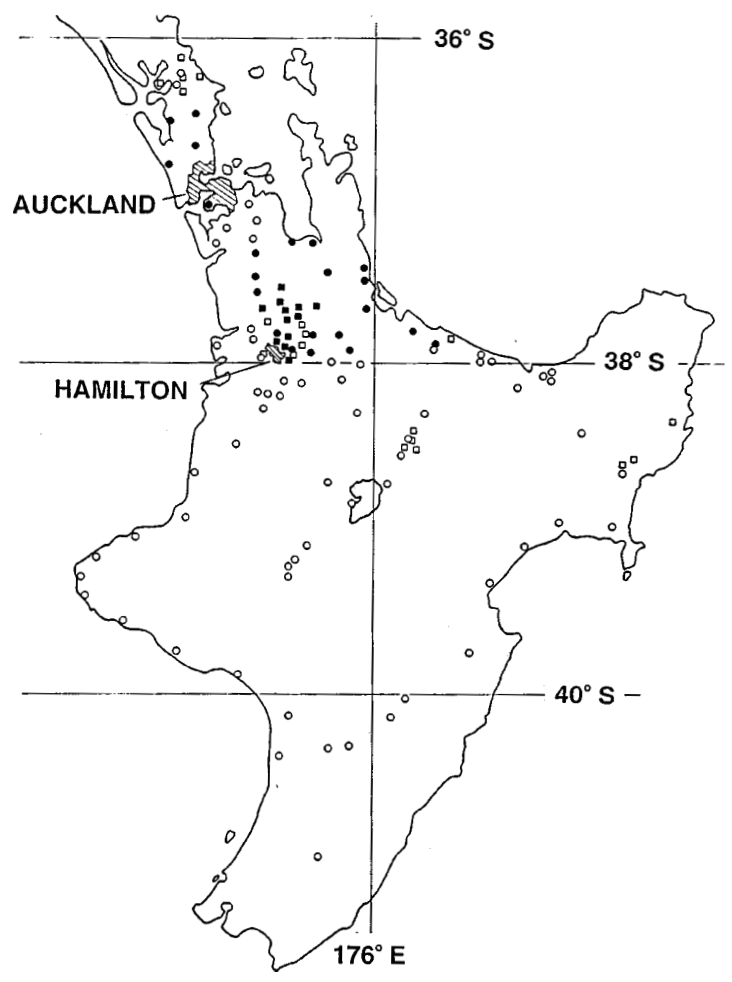

FIGURE 1: Distribution of pasture sites sampled in the North Island of New Zealand and the presence of Sitona lepidus. March - October 1995 samples: $\square$ S. lepidus not detected, $\square$ S. lepidus present; January to April 1996 samples: $O$ S. lepidus not detected, $S$. lepidus present.

During the March-April 1996 survey, numbers of S. lepidus in samples varied greatly between sites. Given that sampling effort was similar for all sites, variation in abundance between sites is indicated. High abundance of S. lepidus (20-160 insects per $100 \mathrm{~m}$ transect) was indicated for sites in Auckland City and to the north, the Hauraki Plains, and the eastern and central Waikato basin. Low abundance (1-5 insects per $100 \mathrm{~m}$ transect) was indicated for pasture sites in the western Waikato and coastal Bay of Plenty.

\section{DISCUSSION}

The collective results of the retrospective and contemporary surveys indicate that S. lepidus is widespread in the Auckland, north Waikato and coastal Bay of Plenty regions. Within this distributional range, there is an apparent zone of absence in South Auckland. The species is apparently absent from southern Northland, southern and western Waikato, southern Bay of Plenty (volcanic plateau), Taupo, King Country, Taranaki, Manawatu, Hawkes Bay and Poverty Bay regions.

Intensive sampling in the Waikato in the 1980s and early 1990 s failed to indicate the presence of any species of Sitona in pasture (Barker and Addison unpublished). In February 1995, weevils, confirmed as S. lepidus in the current study, were obtained 
from several pasture sites in an arc north-west through north to south-east of Hamilton. By the summer of 1995-96, S. lepidus had become common in pastures at Ruakura. Adult weevils were first detected in quantitative soil sampling in March 1996, at 14/ $\mathrm{m}^{2}$, in a pasture sampled intensively since 1991 (Barratt et al. 1996). Recent establishment of S. lepidus and rapid increase in its numbers in pastures at Ruakura were indicated. The March-April 1996 survey indicated similarly high abundance at sites in Auckland City and to the north, the Hauraki Plains, and the eastern and central Waikato basin. In contrast, low abundance of S. lepidus was recorded for pasture sites in the western Waikato and coastal Bay of Plenty. The latter areas may represent sites of most recent colonisation.

\section{CONCLUSIONS}

It is clear that $S$. lepidus is widely established in the northern North Island and therefore beyond the scope of an eradication programme. The date of introduction into New Zealand can not be determined from the available data. However, establishment in the vicinity of Hamilton within the last five years is indicated. The current dispersion and abundance pattern, with apparent absence of infestation in south Auckland, suggests two centres of establishment and spread, one centred around Auckland, the other in the Waikato.

\section{ACKNOWLEDGEMENTS}

This work was funded by MAF Regulatory Authority and by the Foundation for Research, Science and Technology. We thank Richard N. Watson for collection of samples from the coastal Bay of Plenty, and to the numerous farmers who allowed us access to their properties for sampling.

\section{REFERENCES}

Barratt, B.I.P., Barker, G.M. and Addison, P.J., 1996. Sitona lepidus Gyllenhal (Coleoptera: Curculionidae), a potential clover pest new to New Zealand. N.Z. Entomol. 19: (in press).

Bright, D.E., 1994. Revision of the genus Sitona (Coleoptera: Curculionidae) of North America. Ann. Entomol. Soc. Am. 87: 277-306.

Dieckmann, L., 1987. Zum taxonomischen Status von Sitona cinnamomeus Allard (Coleoptera, Curculionidae). Beitr. Ent. Berlin 37: 143-145.

Esson, M.J., 1975. Notes on the biology and distribution of three recently discovered exotic weevil pests in the Hawkes Bay. Proc. 28th N.Z. Weed and Pest Control Conf:: 208-212.

Ferguson, C.M., Roberts, G.M., Barratt, B.I.P., Evans, A.A. and Popay, A.J., 1994. The distribution of the parasitoid Microctonus aethiopoides Loan (Hymenoptera: Braconidae) in southern South Island Sitona discoideus Gyllenhal (Coleoptera: Curculionidae) populations. Proc. 47th N.Z. Plant Prot. Conf: 261-265.

Goldson, S.L. and French, R.A., 1983. Age-related susceptibility of lucerne to sitona weevil Sitona discoideus Gyllenhal (Coleoptera: Curculionidae), larvae and the associated patterns of infestation. N.Z. J. Agri. Res. 26: 251-255.

Goldson, S.L. and Proffitt, J.R., 1986. The seasonal behaviour of the parasite Microctonus aethiopoides and its effects on sitona weevil. Proc. 39th N.Z. Weed and Pest Control Conf:: 122-125.

Goldson, S.L., Proffitt, J.R. and Barlow, N.D., 1994. Sitona discoideus (Gyllenhal) and its parasitoid Microctonus aethiopoides Loan: a case study in successful biological control. Pp. 236-239 In: Pest Control and Sustainable Agriculture. S.A.Corey, D.J. Dall. and W.M. Milne, (Eds.). CSIRO, Division of Entomology, Canberra.

Kain, W.M. and Trought, T.E.T., 1982. Lucerne for the 80's. Agronomy Society of New Zealand. 49-59 pp.

Stufkens, M.W., Farrell, J.A. and Goldson, S.L., 1987. Establishment of Microctonus aethiopoides, a parasitoid of the sitona weevil in New Zealand. Proc. 40th N.Z. Weed and Pest Control Conf:: 31-32. 